\title{
SUITABILITY OF CHARCOAL FROM SELECTED TROPICAL PLANTS FOR THE PRODUCTION OF BLASTING BLACK POWDER
}

\author{
Z.O Opafunso \\ Department of Mining Engineering, \\ The Federal University of Technology, \\ Akure, Nigeria
}

\begin{abstract}
The performance characteristics of charcoal samples of five tropical plants were evaluated for the production of black powder for blasting, sporting and firework purposes. The charcoal produced from each of the tropical plants was used in combination with potassium nitrate and sulphur to produce black powders in the ratio of 2:3:0.5. With the foreign black powder as control, the produced black powders were subjected to ignition/deflagration field tests. The results show that the flame from the ignition of the black powder of trema orientalis were similar to that of foreign black powder. They were reddish in nature intermixed with yellowish colour and, therefore, would be suitable for blasting purposes. Also, that of manihot esculentas would do well for use as gunpowder for sporting purposes while that of cajanus cajan would be an ideal ingredient for the making of fireworks and Christmas "bisco" light. The performances of that of bambusa spp and tectona grandis were too poor for efficient blasting, sporting or firework purposes.
\end{abstract}

Keywords: Explosive, charcoal, blasting, powder, plants.

\section{INTRODUCTION}

Explosives can be defined as substances that decompose rapidly under certain conditions with the production of gases, which expand by the heat of the reaction (Dick et al, 1983). They are substances that produce a rapid, violent reaction when exposed to heat, a strong blow or special detonator (Anon, 1977). During the reaction, explosives give off large amounts of gases at high pressure. The powerful blast of energy released during an explosion allows explosives to be used for mining, construction and military purposes.

Long before explosives, especially black powder, were invented, people used to break up hard rocks with tools and by the heat-and-cold method. They learned that hot objects would crack if they were cooled too quickly, the theory being that when a rock is heated, it stretches a little and when it is cooled, it shrinks. If the temperature change is forced on it too quickly, it will crack, as a glass of hot water will crack, when it is suddenly put under cold water (Starfied, 1997).

Knight (2001) reported that charcoal (C) is one of the principal ingredients used to make black powder and identified willow, alder and grapevine as some of the "soft wood" commonly used for this purpose. These trees are temperate plants, thus this study was initiated to evaluate some selected tropical plant materials that will produce the right " $\mathrm{C}$ " for the production of black powder. This is desirable as not all wood provides the right " $\mathrm{C}$ ' for black powder production. The availability of cheap and good quality locally made black powder is also desirable for the country's economy. Evdokimov (2002) reported that black powder, aka "cannon powder" is a mixture of $\mathrm{C}, \mathrm{S}$ (Sulphur) and $\mathrm{KNO}_{3}$ (Potassium Nitrate) where $\mathrm{C}$ and $\mathrm{S}$ are fuels and $\mathrm{KNO}_{3}$ is an oxidizer, because it does not need air to burn. According to him, not all ratios of black powder mixture produce the satisfying bang (explosions). Typically, ratios like 3:2:0.5 (weight) were very common. He opined that when black powder burns, the reaction is as follows:

$$
\mathrm{KNO}_{3}+\mathrm{C}+\mathrm{S}=\mathrm{K}_{2} \mathrm{~S}+\mathrm{CO}_{2}+\mathrm{N}_{2}
$$


Opafunso et all (2003) reported in their sieve analyses of charcoal used for explosive production that the charcoal sample of trema orientalis will be more adaptable for blasting black powder production because of its coarse nature. In the same vein, it is necessary that the burning characteristics of black powder be analyzed to determine which tropical plant materials would be suitable for use as black blasting powder, sporting black powder and firework black powder. GOEX (2002) suggested that this quality could be determined through the quality of the flame produced during burning/deflagration. The flame produced from such burning is often made a reference point, as good black powder burn relatively fast accompanied with big flame while bad ones burn slowly with small flame. The spread of the flame and the colour produced are also good indicators in the determination of the quality of a typical black powder. Therefore, the objective of the study was to evaluate the performance characteristics of charcoals of five selected tropical plant materials as raw materials for explosive production.

\section{MATERIALS AND METHODS}

Samples of mature tropical plant materials namely: Bambusa spp (bamboo), Manihot esculentas (cassava), Cajanus cajan (pigeon pea), Trema orientalis (charcoal tree) and Tectona grandis (teak) were used to produce charcoal samples in a furnace at $350^{\circ} \mathrm{C}$. Plates 1 to 5 show typical stands of the tropical plant materials in their natural environment. The charcoal produced from each of the tropical plant materials was combined with locally obtained potassium nitrate and sulphur to produce black powder using the following procedure: Potassium Nitrate $\left(\mathrm{KNO}_{3}\right)$, Charcoal (C) and Sulphur (S) were mixed together in the ratio of 3:2:0.5 (Evdokimov, 2002). The mixture was put in a big aluminum cooking pot and water added to form a paste. The pot with the mixture was put on wood-fire and lighted with matches. The mixture was then mixed thoroughly and continuously with wooden stick, until it formed a semi-liquid black gelatinous substance. As the need arose, combustible materials like dry leave, old newspaper and palm kernel seed wastes were added to increase the heat intensity. The quantities of combustible material added were just enough to fill the space under the pot. Continuous agitation and mixing were ensured until a semi-solid black substance formed. At this point, the quantity of heat supplied was reduced, as mixing with the wooden stick continued, until the transformation of the semi-liquid to black grain sizes, which indicates that the process had been completed.

A study of the deflagration characteristics of the black powders produced from the charcoal samples was undertaken by subjecting the newly produced black powders to field tests. For the field tests, $200 \mathrm{~g}$ each of the foreign black powder and from the newly produced black powder were weighed into separate flat plate and ignited with matches to produce different flame colour and intensity. The foreign black powder that was used as control was obtained locally but had been tested to be effective for blasting and sporting purposes (Opafunso, 2003). It was produced in the ratio of 3:2:0.5 for $\mathrm{KNO}_{3}$ : C: S respectively. Two snap shots of each of these deflagrations were quickly recorded with an automatic camera stationed nearby, to observe the ignition lift-up time, colour mix, intensity and the spread of the flame. The snap shots were taken twice as a check on possible ignition errors, which could emanate from bad ignition timing and unfavourable wind direction. All other flames produced by the newly produced black powder were compared with this foreign one. 

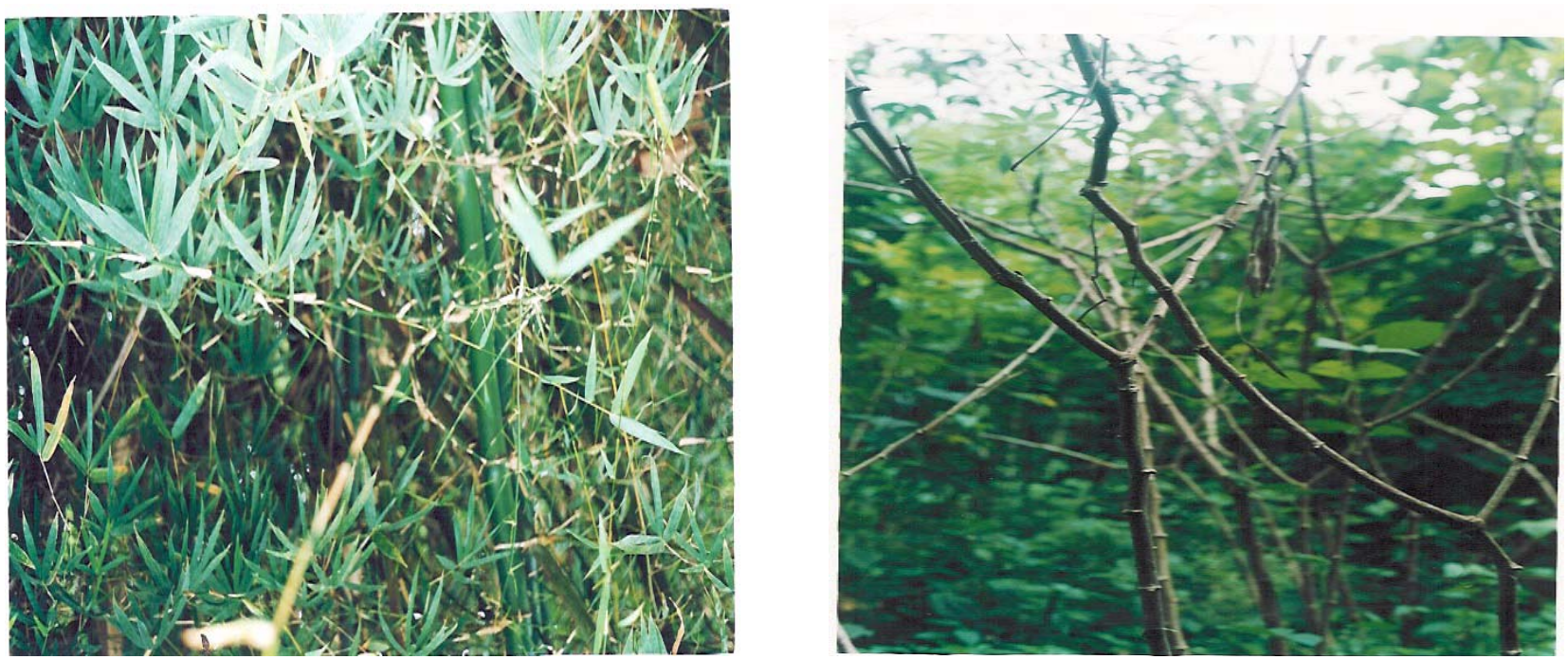

Plate 1: Bambussa Spp (Bamboo)

Plate 2: Manihot Esculentas (Cassava)
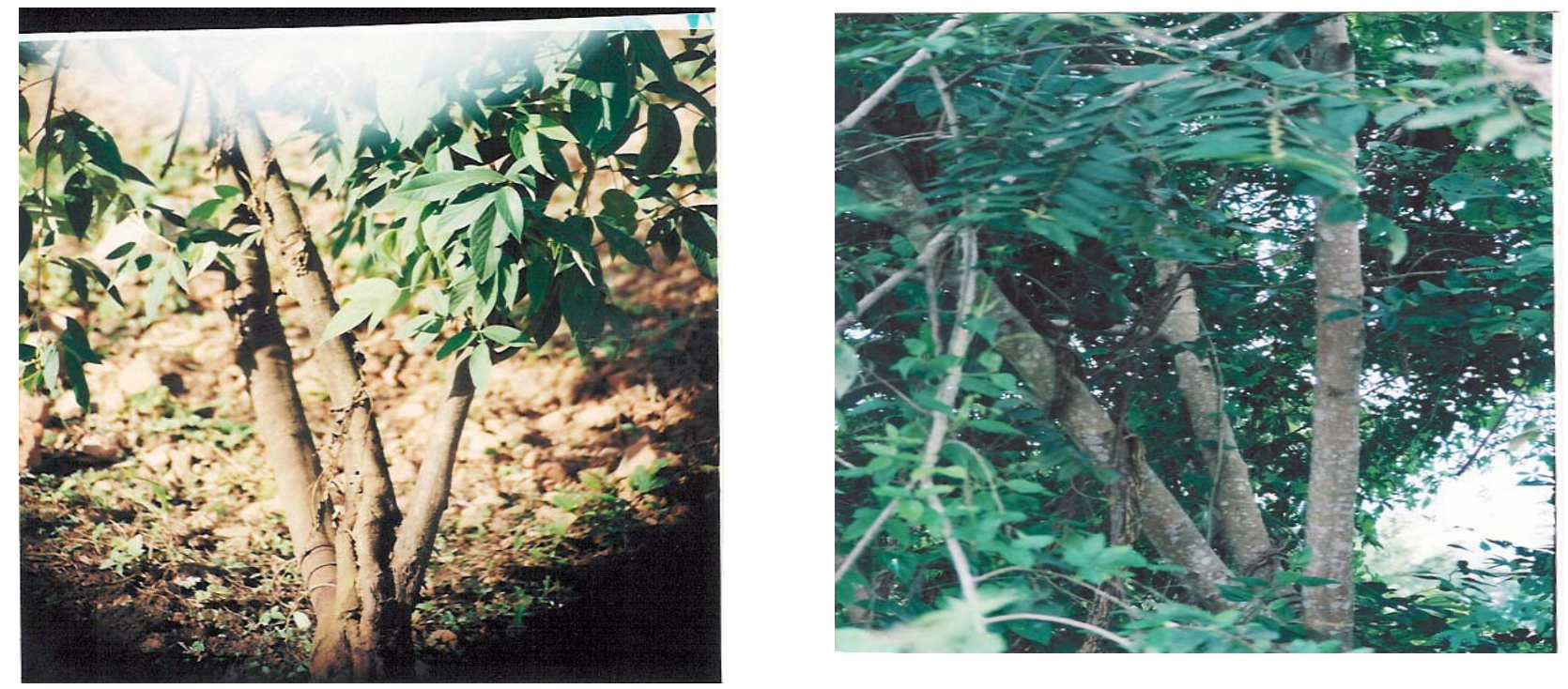

Plate 3: Cajanus Cajan (Pigeon pea)

Plate 4: Trema Orientalis (Charcoal tree)

Plate 5: Tectona Grandis (Teak)

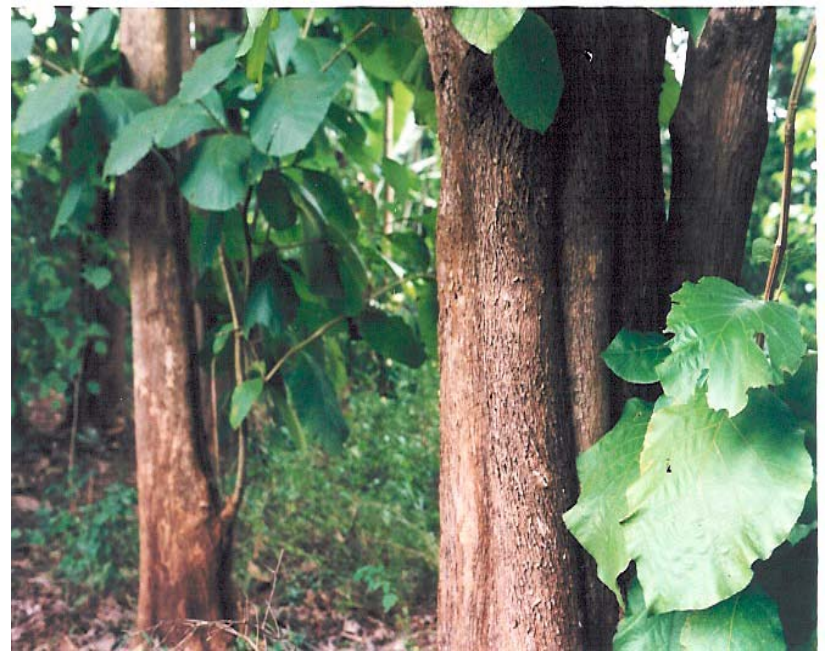




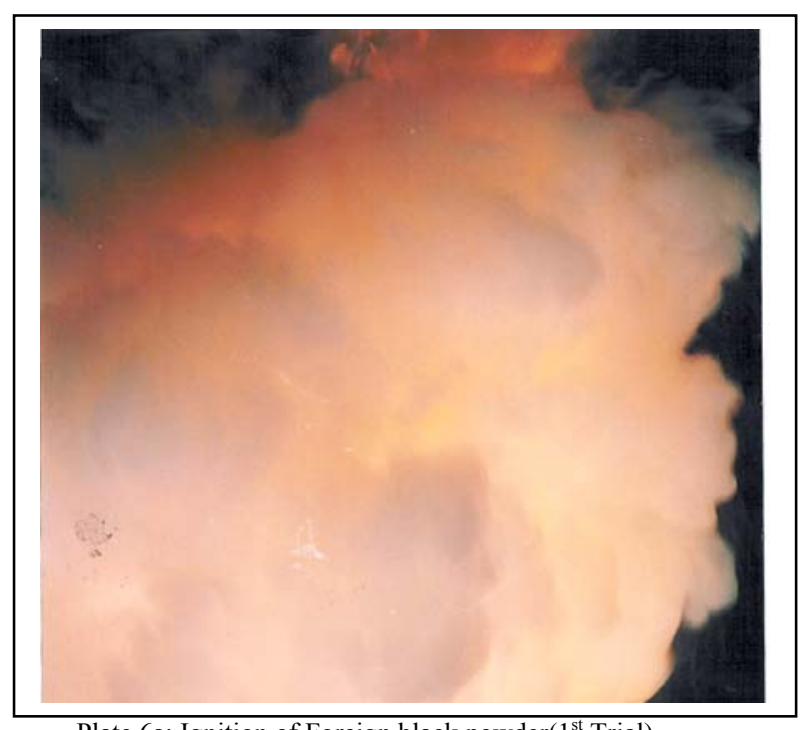

Plate 6a: Ignition of Foreign black powder( $\left(1^{\text {st }}\right.$ Trial $)$
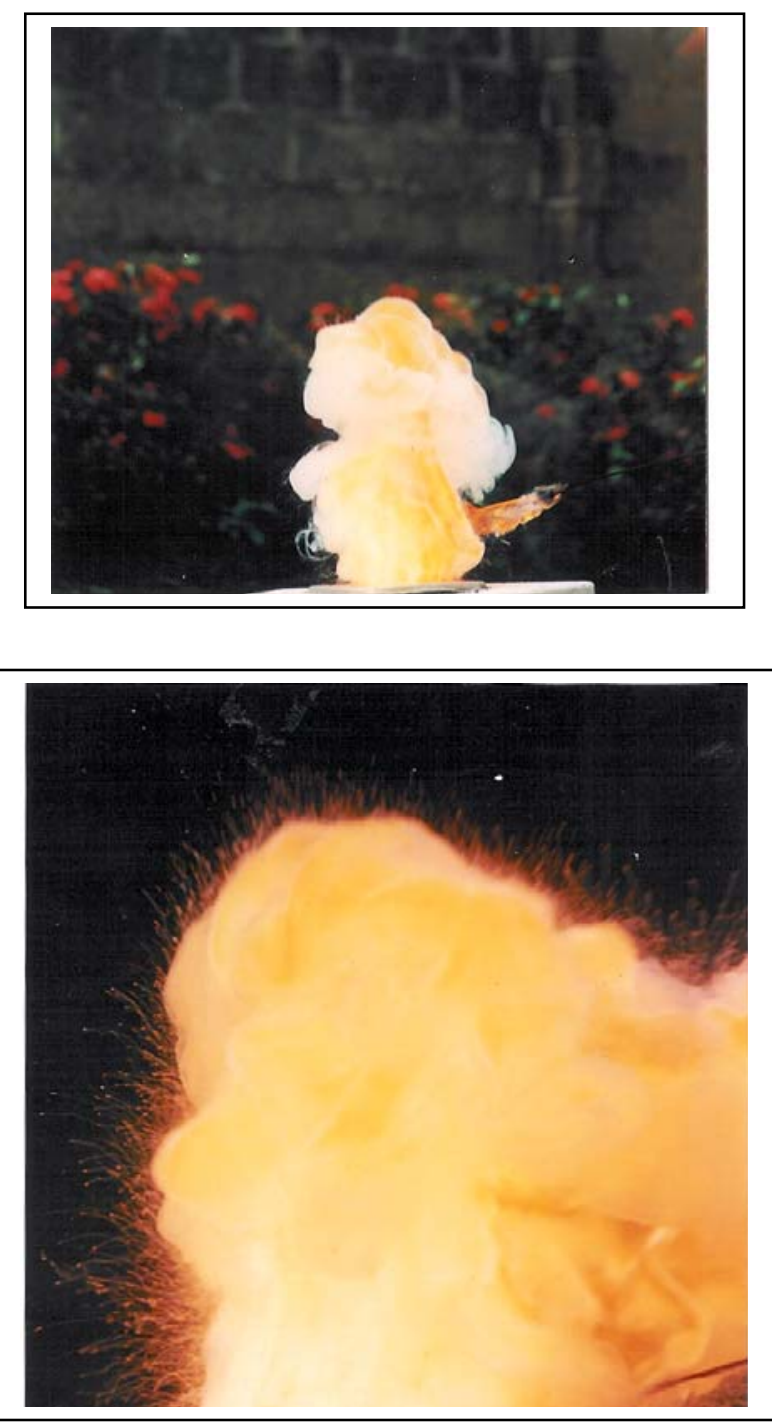

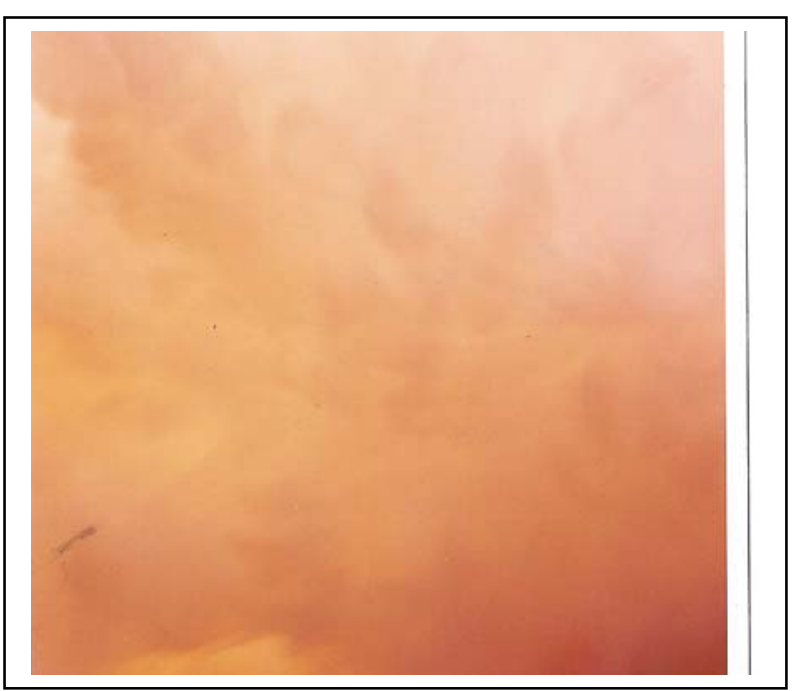

Plate 6b: Ignition of Foreign Black Powder ( $2^{\text {nd }}$ Trial $)$
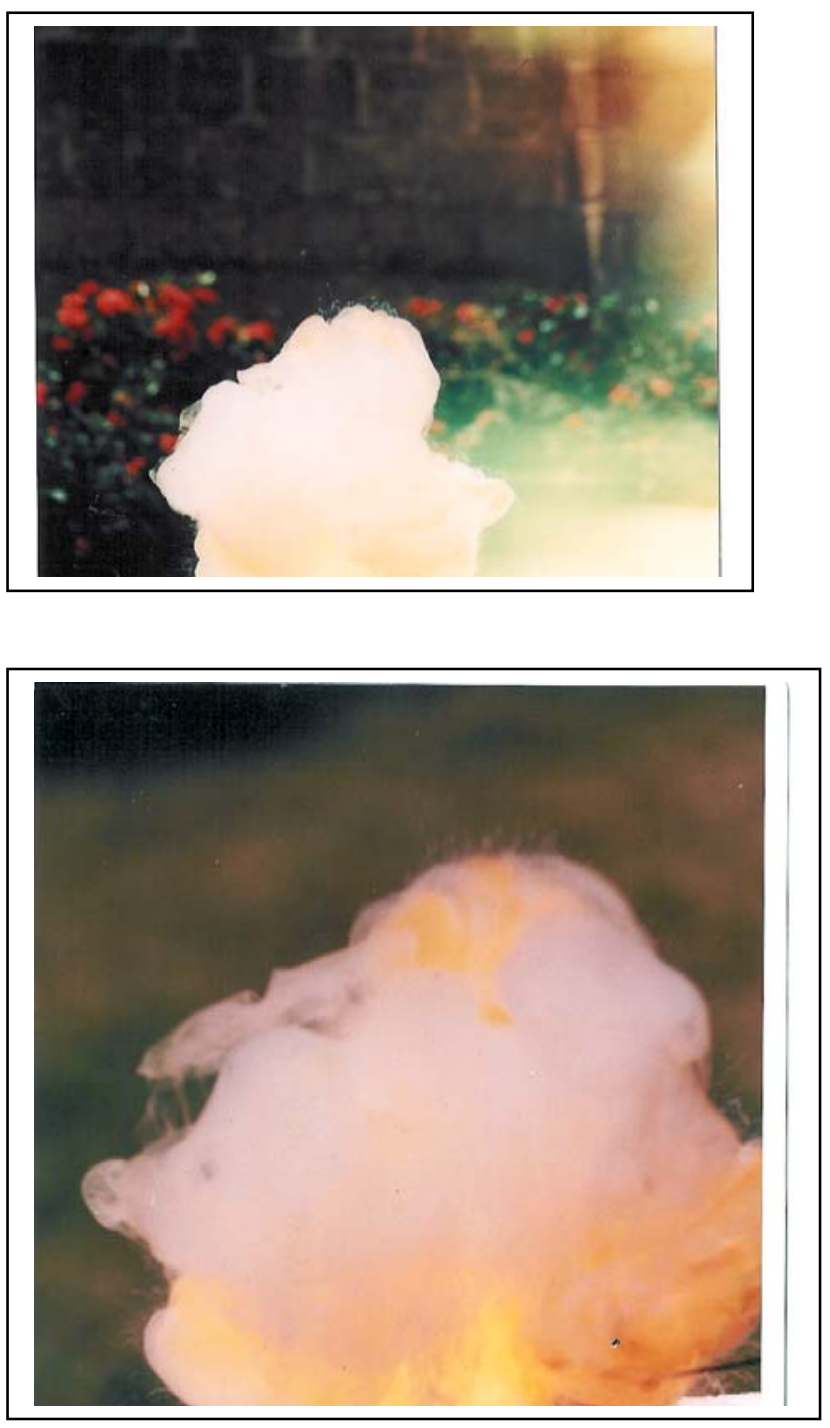

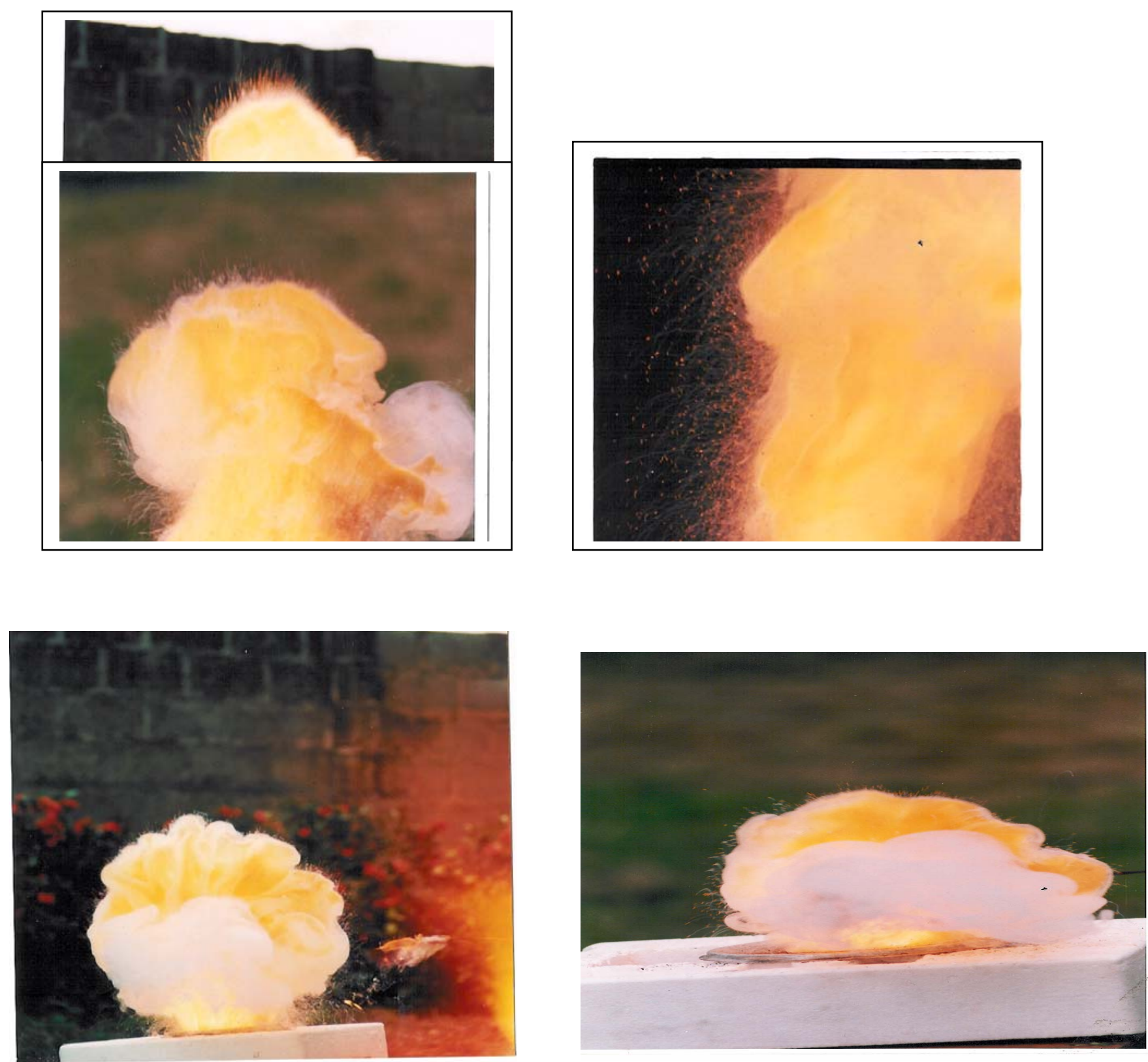

Plate 11a: Ignition from the black powder of Tectona Grandis ( $1^{\text {st }}$ Trial) Plate 11b: Ignition from the black powder of Tectona Grandis $\left(2^{\text {nd }}\right.$ Trial $)$

The major problem encountered was that the temperature of the flame intensity could not be measured because the ignition/deflagration of the explosive occurred so fast (in millisecond) that available temperature measuring apparatus could not record it.

\section{RESULTS AND DISCUSSION}

Close observation of the deflagration of the blasting black powder shows that the flame produced differs from one tropical plant species to another. Plates 6 to 11 show the photographs of the flame produced during the deflagration of the foreign and locally produced black powders. The results of field tests and findings are shown in Table 1. 
Plates $6 \mathrm{a}$ and $6 \mathrm{~b}$ show the first and second trials of the ignition of foreign black powder, which was used as control. Plates $7 \mathrm{a}$ and $7 \mathrm{~b}$ show the first and second trials of the ignition of bambusa spp. The characteristics of these flames were different from that of the foreign black powder and the other black powder. As shown in Table 1 this black powder would not perform efficiently well for blasting, sporting nor for firework purposes.

The flames produced from the first and second trials of the ignition of manihot esculentas are shown in plates 8a and 8b. Apart from the colour different these flames show similar characteristics with that of foreign black powder. As a result of these characteristics and fine nature of the grain sizes of its charcoal samples, the black powder of manihot esculentas would do well for use as gunpowder for sporting purposes. Plates $9 \mathrm{a}$ and $9 \mathrm{~b}$ show the first and second trials of the ignition of the black powder of cajanus cajan. Table 1 shows that these characteristics and the fine nature of the grain sizes of its charcoal would make this black powder an ideal ingredient for making fireworks and Christmas "bisco" light. Plates 10a and 10b show the flames produced from the first and second trials of the ignition of the black powder from trema orientalis. Table 1 shows that the flames exhibited characteristics that were close to that of the foreign black powder, which has successfully been used for blasting purposes. This confirms an earlier study that the black powder of trema orientalis shows a good potential for blasting in dimensional stone quarries (Opafunso, 2003). The flames produced from the black powder of tectona grandis are shown in plates 11a and 11b. As shown in Table 1 the characteristics of the flames were not in any way close to the "control" flame from that of foreign black powder, and therefore would not perform well for blasting, sporting nor for firework purposes.

Table 1: Results of Field Tests

\begin{tabular}{|c|c|c|c|c|}
\hline \multirow{2}{*}{$\begin{array}{l}\text { Source of Black } \\
\text { Powder }\end{array}$} & \multicolumn{3}{|c|}{ Field Observations } & \multirow{2}{*}{ Remark/Findings } \\
\hline & Colour of flame & Spread of flame & $\begin{array}{l}\text { Ignition lift-up } \\
\text { time }\end{array}$ & \\
\hline $\begin{array}{l}\text { Foreign Black } \\
\text { powder }\end{array}$ & $\begin{array}{l}\text { Red intermixed with } \\
\text { yellow }\end{array}$ & $\begin{array}{l}\text { Wide spread above } \\
\text { and around the } \\
\text { ignition base }\end{array}$ & Fast & $\begin{array}{l}\text { Good for blasting and } \\
\text { sporting purposes }\end{array}$ \\
\hline $\begin{array}{l}\text { Black Powder of } \\
\text { Bambusa spp }\end{array}$ & $\begin{array}{l}\text { White intermixed with } \\
\text { yellow at the base }\end{array}$ & $\begin{array}{l}\text { Poor spread from the } \\
\text { base }\end{array}$ & Slow & $\begin{array}{l}\text { Not good for blasting, } \\
\text { sporting nor firework } \\
\text { purposes. }\end{array}$ \\
\hline $\begin{array}{l}\text { Black Powder of } \\
\text { Manihot } \\
\text { Exculentas. }\end{array}$ & $\begin{array}{l}\text { Yellow intermixed } \\
\text { with red }\end{array}$ & $\begin{array}{l}\text { Widespread above and } \\
\text { around the base }\end{array}$ & Fast & $\begin{array}{l}\text { Good for sporting } \\
\text { purposes }\end{array}$ \\
\hline $\begin{array}{l}\text { Black Powder of } \\
\text { Cajanus Cajan }\end{array}$ & $\begin{array}{l}\text { Yellow intermixed } \\
\text { with reddish firework } \\
\text { from the flame edges }\end{array}$ & $\begin{array}{l}\text { Broad from the base } \\
\text { to the edges }\end{array}$ & Fast & $\begin{array}{l}\text { Good for fireworks } \\
\text { and Christmas 'bisco' } \\
\text { light }\end{array}$ \\
\hline $\begin{array}{l}\text { Black Powder of } \\
\text { Trema Orientalis }\end{array}$ & $\begin{array}{l}\text { Red, intermixed with } \\
\text { yellow }\end{array}$ & $\begin{array}{l}\text { Widespread above and } \\
\text { around the base }\end{array}$ & Fast & $\begin{array}{l}\text { Good for blasting and } \\
\text { sporting purposes }\end{array}$ \\
\hline $\begin{array}{l}\text { Black Powder of } \\
\text { Tectona Grandis }\end{array}$ & $\begin{array}{l}\text { White intermixed with } \\
\text { red }\end{array}$ & $\begin{array}{l}\text { Poor spread from the } \\
\text { base }\end{array}$ & Slow & $\begin{array}{l}\text { Not good for blasting, } \\
\text { sporting nor sporting } \\
\text { purposes }\end{array}$ \\
\hline
\end{tabular}

\section{CONCLUSIONS}

The performance characteristics of charcoal samples of bambusa spp, manihot esculentas, cajanus cajan, trema orientalis and tectona grandis in the production of black powder for blasting, sporting and firework purposes had been evaluated. The flames from the ignition of the black powder of trema orientalis were comparable to that of the foreign black powder, which has successfully been used for 
blasting purposes. The flames produced from the black powder of manihot esculentas, were different from that of the foreign black powder but the flame spread was similar to it. Also, as a result of the fine nature of the grain sizes of its charcoal samples, the black powder of manihot esculentas would do well for use as gunpowder for sporting purposes. The characteristics and the fine nature of the grain sizes of charcoal from cajanus cajan would make it's black powder ideal for making fireworks and Christmas "bisco" light. The flames produced from tectona grandis and bambusa spp would not perform efficiently well for blasting, sporting nor for firework purposes. This makes it imperative for further research to be carried out to determine the suitability of other tropical "soft" and "hard" woods for the production of blasting black powder. Determination of the flame intensity during deflagration would also enhance the assessment of the quality of the charcoal for the production of blasting black powder.

\section{REFERENCES}

Anon D. K (1977): Blaster's Handbook, Du Pont De Nemours \& Co, Wilmington, p 130.

Dick R.A. Flecher L.R and D'Andrea D.V (1983): Explosives and Blasting Procedures Manual, U.S. Bureau of Mines I.C., No. 8925. Govt. Print Office, Washington, DC, P 88.

Evdokimov A. (2002): The Chemistry of Black Powder and Explosives, Macmillan Publishers, Oxford, pp 4-6.

GOEX (2002): Production of Black Powder - Handling Precautions and Specifications, GOEX line, Doyline, Louisiana, $\mathrm{p} 5$.

Knight R. (2001): Black Powder Compositions, Official Publication of the International Blackpowder Hunting Association, Glenrock, Wyoming, USA p 1.

Opafunso Z.O (2003): "Evaluation of Selected Tropical Plants Materials as Sources of Carbon in the Production of Explosives for Dimension Stone Production", Unpublished Ph.D. thesis, The Federal University of Technology, Akure, Nigeria, 287pp.

Opafunso Z.O. Onyemaobi O.O and L. Lajide (2003): Sieve Analyses of charcoal Used for Explosive Production, Nigerian Journal of Technological Development, Faculty of Engineering, University of Ilorin, Nigeria, pp 117-125.

Starfied A.M. (1997): The value of Theory in Blasting Design, Proceedings of the twenty-eighth Annual University of Minnesota Mining Symposium, Duluth, Minnesota, p 11. 